\title{
[Supporting Information] Revealing the membrane-bound catalytic oxidation of NADH by the drug target Type-II NADH Dehydrogenase
}

\author{
Albert Godoy-Hernandez ${ }^{\dagger, \S}$, Daniel J. Tate ${ }^{\ddagger}$, and Duncan G. G. McMillan ${ }^{\dagger, \S, \#^{*}}$ \\ $\dagger$ Department of Biotechnology, Delft University of Technology, Van der Maasweg 9, 2629 HZ Delft, The Netherlands \\ * School of Chemistry, University of Manchester, Oxford Road M13 9PL Manchester, United Kingdom \\ \# Department of Applied Chemistry, Graduate School of Engineering, The University of Tokyo, Tokyo 113-8656, Japan
}

\section{METHODOLOGY}

CthNDH-2 Overexpression and purification-Escherichia coli BL21 (DE3) cells were transformed with pTrc99A containing the gene coding for $C$ thNDH-2 and grown in $2 x Y T$ medium $(16 \mathrm{~g} / 1$ tryptone, $10 \mathrm{~g} / \mathrm{l}$ Yeast Extract, $5 \mathrm{~g} / \mathrm{l} \mathrm{NaCl})$ at $37^{\circ} \mathrm{C} 180$ $\mathrm{rpm}$, supplemented with $100 \mu \mathrm{g} / \mathrm{mL}$ ampicillin. Once the culture had reached $\mathrm{OD}_{600} 0.5, \mathrm{NDH}-2$ expression was induced using $1 \mathrm{mM}$ isopropyl $\beta$-Dthiogalactopyranoside (IPTG, Sigma Aldrich, Germany). Cells were grown for a further $4 \mathrm{~h}$ before being harvested by centrifugation and pellets were stored at $-20^{\circ} \mathrm{C}$. Cell pellets were resuspended in cell lysis buffer (50 mM Tris- $\mathrm{HCl}$ containing $2 \mathrm{mM} \mathrm{MgCl}_{2}, \mathrm{pH} 7.5$ ) containing $0.1 \mathrm{mM}$ PMSF and $0.1 \mathrm{mg} / \mathrm{ml}$ of pancreatic DNase. Cells were then resuspended, and disrupted using a cell disruptor (Constant Systems, Ltd, UK) at 35 kpsi. Unbroken cells and cell debris were removed by centrifugation at $10,000 \times g$ for $20 \mathrm{~min}$ at $4^{\circ} \mathrm{C}$. The membrane fraction was isolated from the cell lysate by ultracentrifugation at $180,000 \times g$ for $1 \mathrm{~h}$ at $4^{\circ} \mathrm{C}$ and washed twice in the same buffer. Membranes were resuspended and solubilized at $5 \mathrm{mg} / \mathrm{ml}$ in solubilization buffer containing $50 \mathrm{mM}$ Tris- $\mathrm{HCl}(\mathrm{pH} 8.0), 10 \mathrm{mM}$ imidazole, $150 \mathrm{mM} \mathrm{NaCl}$ and $2 \%(\mathrm{w} / \mathrm{v})$ n-octyl- $\beta$-Dglucopyranoside (OG) (Anatrace, USA), with gentle stirring at $4^{\circ} \mathrm{C}$ for $1 \mathrm{~h}$. Insoluble material was subsequently removed by ultracentrifugation at 180,000 $\times g$ for $1 \mathrm{~h}$ at $4^{\circ} \mathrm{C}$. Solubilized membrane proteins were loaded onto a HisTrap HP column using an NGC Chromatography System (BioRad, USA), equilibrated with 7 column volumes of buffer A $(50 \mathrm{mM}$ Tris- $\mathrm{HCl}$ (pH 8.0), $20 \mathrm{mM}$ imidazole, $150 \mathrm{mM} \mathrm{NaCl}$ and $1 \% \mathrm{w} / \mathrm{v}$ OG). Unbound sample was removed by washing with 5 column volumes of buffer $\mathrm{A}$, before elution with a linear gradient of buffer B [50 mM Tris- $\mathrm{HCl}(\mathrm{pH} 8.0), 500$ $\mathrm{mM}$ imidazole, $150 \mathrm{mM} \mathrm{NaCl}$ and $1 \% \mathrm{w} / \mathrm{v}$ OG] over 15 column volumes reaching $100 \%$ buffer B. Fractions containing $C t h \mathrm{NDH}-2$ were concentrated using $50 \mathrm{kDa}$ molecular weight cutoff column (Amicon) before buffer exchange into $50 \mathrm{mM}$ Tris- $\mathrm{HCl}(\mathrm{pH} 8.0), 20 \mathrm{mM}$ imidazole, $150 \mathrm{mM} \mathrm{NaCl}$ and $0.005 \%$ lauryl maltose neopentyl glycol (LMNG; Anatrace).

Sodium dodecyl sulfate (SDS)-polyacrylamide gels (PAGE) and Protein Quantification-CthNDH-2 and mutant variant preparations were routinely analyzed on $12 \%$ SDS-PAGE. Polypeptide bands were visualized using Coomassie brilliant blue (Bio-Rad, USA). Protein concentrations were determined using a bicinchoninic acid (BCA) protein assay kit (Sigma) with bovine serum albumin as the standard.

Lipid treatment and reconstitution-All lipids in this study were purchased from Avanti Polar Lipids, Inc., Alabaster, AL. Stock solutions of native E. coli polar lipids extract ( $n$ ECPL), were dried under an $\mathrm{N}_{2}$ stream. When used, different concentrations of menaquinone $\left(\mathrm{MQ}_{7}\right)$ were added to the chloroformdissolved lipid mixtures and dried together. Vesicles were resuspended in $20 \mathrm{mM}$ Tris(hydroxymethyl)aminomethane hydrochloride (Tris$\mathrm{HCl}$, Sigma) buffer containing $100 \mathrm{mM} \mathrm{KCl}$. All vesicles concentrations after resuspension were 10 $\mathrm{mg} / \mathrm{mL}$. These were then extruded 11 times through a $400 \mathrm{~nm}$ track edge membrane using an extruder (Avanti Polar Lipids, Inc., Alabaster, AL). Purified Caldalkalibacillus thermarum NDH-2 and mutants were then reconstituted onto an ECPL bilayer by autoinsertion reconstitution at a concentration of $0.2 \mathrm{mg} / \mathrm{ml}$ as described elsewhere ${ }^{l}$.

Solution-phase NADH:quinone oxidoreductase assays - The NADH:quinone oxidoreductase activity was measured using a spectrophotometric assay as previously described ${ }^{2}$. It was monitored spectrophotometrically by following the oxidation of $\mathrm{NADH}$ at $340 \mathrm{~nm}$ in the presence of menadione (Cary $60 \mathrm{UV} / \mathrm{Vis}$ Spectrophotometer, Agilent Technologies). Temperature conditions were controlled using a thermostatic stirring unit (Quantum Northwest). NADH 
(final concentration $100 \mu \mathrm{M}$ ) and menadione were added

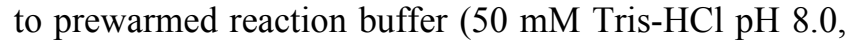
$150 \mathrm{mM} \mathrm{NaCl}$, final volume $2 \mathrm{ml}$ ) in a $1 \mathrm{~cm}$ path length PMMA cuvette and incubated for $30 \mathrm{~s}$. Enzymatic preparations of $C t h \mathrm{NDH}-2(0.2 \mu \mathrm{g})$ were added to the mixture to initiate the reaction. The extinction coefficient of $6.22 \mathrm{mM}^{-1} \mathrm{~cm}^{-1}$ was used to calculate NADH concentration and NDH-2-specific activity was expressed as $\mathrm{U}$ mg protein $^{-1}$, where $1 \mathrm{U}=1 \mu \mathrm{mol}$ NADH oxidized $\min ^{-1}$. To determine the $\mathrm{V}_{\max }, \mathrm{k}_{\text {cat }}$ and apparent $\mathrm{K}_{\mathrm{M}}$ for enzyme activity was measured with menadione concentrations being varied and data fitted to the Michaelis-Menten equation by non-linear leastsquares regression.

\section{Surface preparation and bilayer formation}

All the experiments were carried out with ultra-flat template stripped gold (TSG) working electrodes. 150 $\mathrm{nm}$ of $99.99 \%$ gold (Goodfellows) was evaporated on silicon wafers using a Telemescal evaporator at $<2 \times 10^{-6}$ mbar. $1.2 \mathrm{~cm}^{2}$ glass slides were glued to the gold layer with Epo-Tek 377 and cured for $2 \mathrm{~h}$ at $120^{\circ} \mathrm{C}$. The TSG surface was exposed by detaching the glass slides from the silicon wafers before use. The formation of the selfassembled monolayers (SAMs) containing the cholesterol "tether" and the formation of the SSM onto the electrode were performed as described previously ${ }^{3}$. SAMs were formed by incubating a freshly exposed TSG slide in $0.11 \mathrm{mM}$ eo3-cholesteryl and $0.89 \mathrm{mM}$ 6mercaptohexanol $(6 \mathrm{MH})$ in propanol for $16 \mathrm{~h}$. Where NDH-2 and Menadione were used, SAMs were made with $1 \mathrm{mM} 6 \mathrm{MH}$ alone. After incubation, the excess thiol was gently washed away with isopropanol and methanol, and the electrodes were then dried in a stream of $\mathrm{N}_{2}$. For bilayer SAMs this procedure results in an approximate $\quad 60 \% / 40 \% \quad$ eo3-cholesteryl $/ 6$ mercaptohexanol area ratio on the surface as confirmed by impedance spectroscopy before each experiment. For SAMs prepared for NDH-2 and Menadione experiments, the surface was coated in $100 \% 6 \mathrm{MH}$. To form tethered lipid membranes (tBLMs), vesicles were added to the SAM surface at a final concentration of $0.5 \mathrm{mg} / \mathrm{ml}$ in the presence of $10 \mathrm{mM} \mathrm{CaCl}_{2}$ and incubated for $1 \mathrm{~h}$ until a capacitance drop to less than $1.2 \mu \mathrm{F} / \mathrm{cm}^{2}$ was observed. The surface was then rinsed three times with water, then buffer containing $0.5 \mathrm{mM}$ EDTA to remove any traces of calcium ions in the cell. Finally, the SAM-modified or vesicle/proteoliposome-modified electrodes were rinsed three times with buffer and used in the electrochemistry experiments. Care was taken to keep the electrodes immersed in an aqueous environment at all times during rinsing.

For protein film voltammetry assays, the $6 \mathrm{MH}$ SAM surface was modified with either $1 \mathrm{mg} / \mathrm{ml} C t h \mathrm{NDH}-2$ or $1 \mathrm{mM}$ MD then $1 \mathrm{mg} / \mathrm{ml} C t h \mathrm{NDH}-2$. Each incubation process was $30 \mathrm{~min}$ in duration. The electrochemical cell was washed 5 times in buffer before and between incubation processes. Cyclic voltammetry were conducted before and after the addition of experimental components.

\section{Cyclic Voltammetry (CV) and Electrochemical Impedance Spectroscopy (EIS).}

A bespoke glass electrochemical cell with temperature control was used with a standard 3-electrode setup ${ }^{4}$. Ultra-flat template-stripped gold (TSG) working electrodes were embedded in a PTFE holder with a rubber $O$-ring seal, $\left(\mathrm{A}=0.2 \mathrm{~cm}^{2}\right)$; a platinum wire counter electrode and a saturated silver/silver chloride electrode $(\mathrm{Ag} / \mathrm{AgCl})$ to complete the circuit in the buffer volume. Routinely, experiments were conducted in a 20 $\mathrm{mM}$ MOPS, $30 \mathrm{mM} \mathrm{Na} \mathrm{SO}_{4}$ at $\mathrm{pH}$ 7.4, buffer. The cell was used in a steel mesh Faraday cage to minimize electrical noise. Electrochemical measurements were recorded at $25^{\circ} \mathrm{C}$ using an Autolab electrochemical analyser with a PGSTAT128N potentiostat equipped with SCAN250, ADC10M , and FRA32M frequency analyser modules (Metrohm). To control SAM quality prior to electrode modification with vesicles, MD or CthNDH-2 EIS impedence spectra were recorded on each SAM electrode prior to the addition of protein. Analogue CVs were routinely recorded at a scan rate of $10 \mathrm{mV} / \mathrm{s}$ on SAMs, bilayers and enzyme/MD modified electrodes prior to and after the addition of the substrate (NADH). All experiments using vesicles, non-directly associated vesicles were washed out after $30 \mathrm{~min}$ incubation. Cyclic voltammetry experiments were routinely carried out by holding the potential at $-0.55 \mathrm{~V}$ for 5 seconds before cycling at a scan rate of $10 \mathrm{mV} / \mathrm{s}$ in the potential window from $-0.55 \mathrm{~V}$ to $0.2 \mathrm{mV}$ (vs $\mathrm{Ag} / \mathrm{AgCl})$. 

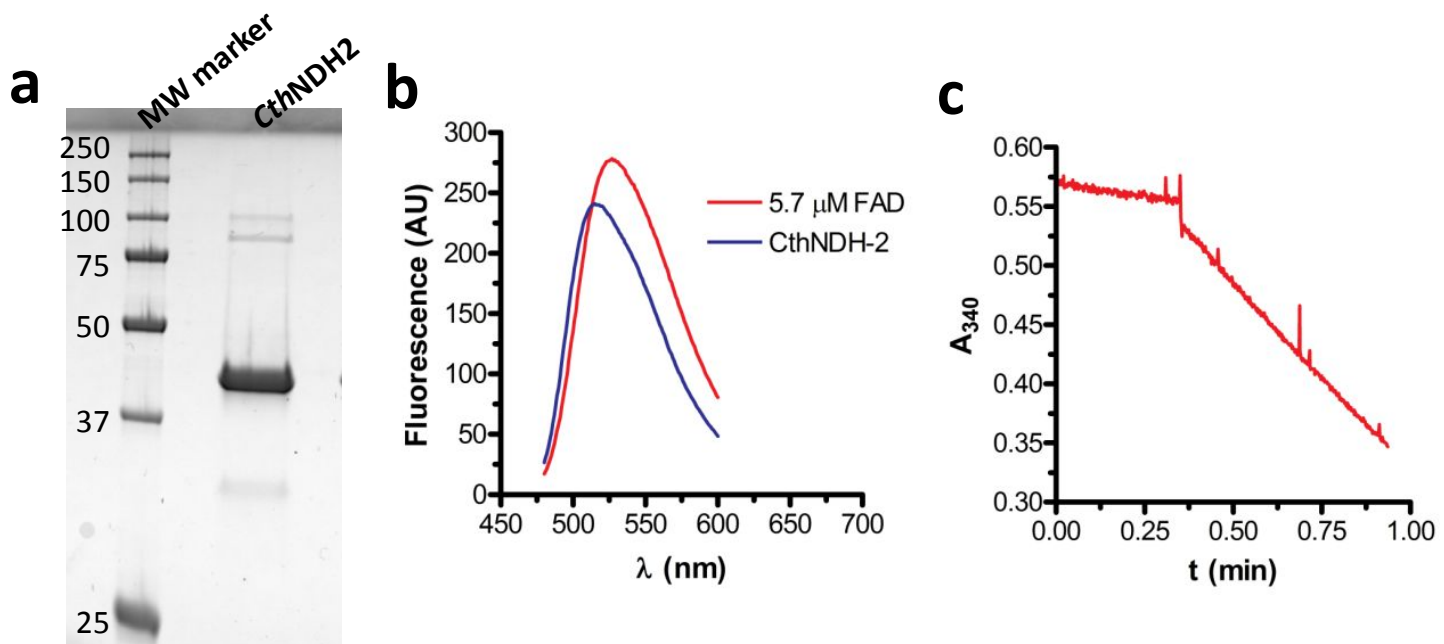

Figure S1: $\boldsymbol{A}$, SDS-PAGE of the purified $C t h N D H 2$. Purification using octyl $\beta$-D-glucopyranoside as a detergent. $\boldsymbol{B}$, fluorescence spectra of FAD and CthNDH2 (excitation $445 \mathrm{~nm}$, emission $524 \mathrm{~nm}, 10 \mathrm{~nm}$ slit). $C$, kinetic traces of NADH oxidation with $C t h \mathrm{NDH} 2$ in solution phase: $100 \mu \mathrm{M}$ NADH, $400 \mu \mathrm{M}$ menadione, $20 \mathrm{mM} \mathrm{MOPS}, 30 \mathrm{mM} \mathrm{Na}_{2} \mathrm{SO}_{4} \mathrm{buffer}_{\text {(pH }}$ 7.4). 
a<smiles>CCC1=C(C)C(=O)c2ccccc2C1</smiles>

b<smiles>CC(C)=CCC/C(C)=C/CC/C(C)=C/CC/C(C)=C/CC1=C(C)C(=O)c2ccccc2C1=O</smiles>

○<smiles>CC(C)=CCC/C(C)=C/CC1=C(C)c2ccc(C)cc2C1=O</smiles>

$\mathrm{OH}$

Figure S2: Structures of menaquinone species $(\boldsymbol{A}-\boldsymbol{B})$ and inhibitors used in this study. $\boldsymbol{A}$, Menadione $\left(\mathrm{MQ}_{0}\right) ; \boldsymbol{B}$, Menaquinone-7 $\left(\mathrm{MQ}_{7}\right) ; \boldsymbol{C}$, N-oxo-2-heptyl-4-Hydroxyquinoline (HQNO).

\section{REFERENCES}

(1) Hards, K., McMillan, D. G. G., Schurig-Briccio, L. A., Gennis, R. B., Lill, H., Bald, D., and Cook, G. M. (2018) Ionophoric effects of the antitubercular drug bedaquiline. Proc. Natl. Acad. Sci. USA 115, 7326-7331.

(2) Heikal, A., Nakatani, Y., Dunn, E., Weimar, M. R., Day, C. L., Baker, E. N., Lott, J. S., Sazanov, L. A., and Cook, G. M. (2014) Structure of the bacterial type II NADH dehydrogenase: a monotopic membrane protein with an essential role in energy generation. Mol. Microbiol. 91, 950-964.

(3) Jeuken, L. J. C., Daskalakis, N. N., Han, X., Sheikh, K., Erbe, A., Bushby, R. J., and Evans, S. D. (2007) Phase separation in mixed self-assembled monolayers and its effect on biomimetic membranes. Sensors and Actuators B: Chemical, 124, 501-509.

(4) McMillan, D. G. G., Marritt, S. J., Kemp, G. L., GordonBrown, P., Butt, J. N., and Jeuken, L. J. C. (2013) The impact of enzyme orientation and electrode topology on the catalytic activity of adsorbed redox enzymes. Electrochim. Acta 110, 79-85. 